\title{
The Effect of Insecticide Application on Plutella xylostella Linn. and its Parasitoid Diadegma sp.
}

\author{
Bambang Tri Rahardjo*, Tita Widjayanti, Antika Anggraini \\ Plant Protection Department, Faculty of Agriculture, University of Brawijaya Jl. Veteran, Malang 65145, East Java, Indonesia
}

Submitted 25 August 2020 Accepted 02 November 2020

Corresponding author Bambang Tri Rahardjo, bambangtri@ub.ac.id

\section{ABSTRACT}

Cabbage is one of the commodities that mostly cultivated in Indonesia, but the cabbage farmers often suffered losses because of pests' attack. The important pests on cabbage is Plutella xylostella. This study aimed to investigate the effectiveness level of an insecticide with active ingredient carbaryl $85 \%$ in controlling $P$. xylostella which attacks cabbage and its impact on the parasitoid of Diadegma sp. This research uses a randomized block design with six treatments and four replications. The treatments were different concentrations of the insecticide carbaryl $85 \%$. The testing on Diadegma sp. used two methods, directly and indirectly test (residual exposure). The carbaryl $85 \%$ was not effective in controlling $P$. xylostella, but the population was decreasing. The carbaryl $85 \%$ with the highest effect in reducing P. xylostella population was $3.0 \mathrm{~g} / \mathrm{l}$. The carbaryl $85 \%$ did not affect on the mortality of natural enemies (Diadegma sp. parasitoid) after direct and indirect test.

Keywords: Carbaryl; cabbage; diamond back moth; parasitoid; pesticide

\section{INTRODUCTION}

Cabbage is a vegetable commodity that is widely cultivated in Indonesia. However, the yield will decrease when there is a pest attack. The important pests on cabbage include Plutella xylostella Linn. (Lepidoptera: Plutellidae) (Capinera, 2018). The damage caused by P. xylostella to cabbage can reach $100 \%$ (Navik et al., 2019). The high level of pest attack on cabbage has made farmers do a variety of ways, from prevention to control using chemical pesticides.

In high $P$. xylostella attacks, farmers will apply insecticides optimally to overcome crop failure. However, the application of insecticides must be carried out as recommended, because overapplied insecticides will increase pest resistance and pest outbreak (resurgence) (Mpumi et al., 2020). If the target pest is resistant to a certain insecticide, it is necessary to increase the dose and frequency of application of that insecticide. This has a negative impact on non-target insects and the environment (Pinheiro et al., 2013).

There are several types of insecticides commonly used by farmers, namely the pyrethroid, carbamate and organophosphate groups (Mavrikou et al., 2008). The order of the negative influence of the insecticide class against natural enemies is pyrethroid, organophosphate, carbamate (Palmquist et al., 2012). Carbamate is a class of insecticides with the lowest negative effect (Morais et al., 2012). 
Farmer has not tested the efficacy of insecticides with active carbaryl ingredients. Therefore, it is necessary to test the effect of insecticides with active carbaryl ingredients on the population of $P$. xylostella and their effects on natural enemies. This study aimed to investigate the effectiveness level of an insecticide with active ingredient carbaryl $85 \%$ in controlling $P$. xylostella which attacks cabbage and its impact on the parasitoid of Diadegma sp.

\section{MATERIALS AND METHODS}

\section{Research Implementation}

This research was conducted in Junrejo Village, Batu City and Pest Laboratory, Department of Plant Pests and Diseases, Faculty of Agriculture, Brawijaya University. The land used as the experimental site was $1 \mathrm{~m} \times 8 \mathrm{~m}$ in size with $50 \mathrm{~cm}$ spacing between plots. The land was planted with cabbage seeds ( 2 weeks old) with a spacing of $50 \mathrm{~cm} \times 50$ $\mathrm{cm}$ with a monoculture cropping system.

\section{Insecticide Application}

This study used a randomized block design (RBD) with 6 treatments and 4 replications. The treatments were carried out by using the difference in the concentration of an insecticide with active ingredient carbaryl 85\% (Table 1). The insecticide application was used a high-pressure semiautomatic back spray with a volume of 500 liters/ ha. Prior to the application of insecticides, preliminary observations were made at 13 days after planting. The next insecticide application was carried out once a week. The control threshold for $P$. xylostella was 5 larvae in 10 sample plants.

The $P$. xylostella population that attacked in each plot was counted directly. In preliminary observations, the population count was carried out every 3 days until the population exceeds the con- trol threshold ( 5 in 10 sample plants). If the population had exceeded the control threshold, the first insecticide application was carried out one day after the preliminary observation. Subsequent observations were carried out 3 days after the first insecticide application to 3 days after the last insecticide application. The number of sample plants observed was 10 plants in each treatment plot. The method used to determine the sample plants were systematically taking the sample plants by counting the plants with multiples of four on each treatment plot.

Direct testing was carried out by sprayed the insecticide carbaryl $85 \%$ directly on the plants that had been covered with tubes and had been added to Diadegma sp. (10 individuals). Insecticide application was carried out by manual spray bottles with a spray volume of $10 \mathrm{ml} /$ plant in each treatment. Then the observations were made by counting the number of Diadegma $s p$. was dead. Observations were made at 24,48 , and 72 hours after application. In tests with residual exposure (indirectly), the application of insecticides was carried out on covered cabbage using a mica tube. Insecticide application was carried out using a spray bottle with a spray volume of $10 \mathrm{ml} /$ plant. After sprayed evenly on all parts of the plant, the plants were left to stand for one hour and then put Diadegma sp. (10 individuals in each treatment). Then observations were made at 24,48 , and 72 hours after application.

\section{Data Analysis}

The data were analyzed using ANOVA with a confidence level of $5 \%$. If the results were significantly different, further tests were carried out using the least significant difference of $5 \%$. All the data were calculated by using SPSS. 
Tabel 1. Insecticide treatment concentrations

\begin{tabular}{lc}
\hline Active ingredients & Concentration \\
\hline Carbaryl 85\% & $0.5 \mathrm{~g} / \mathrm{l}$ \\
Carbaryl 85\% & $1.0 \mathrm{~g} / \mathrm{l}$ \\
Carbaryl 85\% & $1.5 \mathrm{~g} / \mathrm{l}$ \\
Carbaryl 85\% & $2.0 \mathrm{~g} / \mathrm{l}$ \\
Carbaryl 85\% & $3.0 \mathrm{~g} / \mathrm{l}$ \\
Control & - \\
\hline
\end{tabular}

\section{RESULTS AND DISCUSSION}

\section{Effect of Insecticide Application on $P$. xylostella Populations}

The results showed that $85 \%$ carbaryl insecticide can cause the mortality of $P$. xylostella. In the first and second observations after application, there was no significant effect between the $85 \%$ carbaryl. The third to the fifth observation after application, there was a significant effect (Table 2). In the observations after the first and second applications, the $85 \%$ carbaryl insecticide treatment had not significant effect on $P$. xylostella populations because the observations after the first application were observations in the seventh week after planting, when the plants were still in the leaf formation phase. When the cabbage plant was still in its leaf formation phase, the $P$. xylostella population was still low. The crop is formed from tightly grown leaves. In the crop formation phase, $P$. xylostella attack will increase. Capinera (2018) states that the presence of larvae in florets can result in complete rejection of produce, even if the level of plant tissue removal is insignificant. This phase is the phase of increasing $P$. xylostella population. According to Kotta, Trisyono, \& Wijonarko (2018), the high population of $P$. xylostella at the eighth week after planting was due to the highest quality and quantity of young leaves at the eighth week after planting.

\section{Effect of Insecticides on Diadegma sp.}

The results showed that the effect of the insecticide carbaryl $85 \%$ directly were not significantly different between treatments on Diadegma sp. (Table 3). The effect of the application of the insecticide carbaryl $85 \%(3.0 \mathrm{~g} / \mathrm{l})$ at 24 until 72 hours after treatment showed the largest decrease in the population of Diadegma sp., while the control treatment did not occur. Carbaryl 85\% (3.0 g/l) was the the highest insecticide dose. According to Capinera (2018), increasing the active insecticide ingredient concentration causes higher mortality of the tested insects. Although the highest mortality was in carbaryl $85 \%$ with $3.0 \mathrm{~g} / \mathrm{l}$, the mortality of Diadegma $s p$. was not significantly different from the control treatment, and the mortality of Diadegma sp. in all treatments did not exceed $50 \%$.

Tabel 2. The average population of $P$. xylostella

\begin{tabular}{lcrcccc}
\hline \multicolumn{2}{c}{ Treatment } & \multicolumn{5}{c}{ Plutella xylostella populations (individuals) } \\
\cline { 3 - 7 } Carbaryl 85\% & $(0.5 \mathrm{~g} / \mathrm{l})$ & 4.75 & 4.50 & $6.50 \mathrm{ab}$ & $10.75 \mathrm{c}$ & $9.50 \mathrm{a}$ \\
Carbaryl 85\% & $(1.0 \mathrm{~g} / \mathrm{l})$ & 3.75 & 6.00 & $9.50 \mathrm{~cd}$ & $10.75 \mathrm{c}$ & $10.00 \mathrm{a}$ \\
Carbaryl 85\% & $(1.5 \mathrm{~g} / \mathrm{l})$ & 2.25 & 3.75 & $7.25 \mathrm{abc}$ & $9.75 \mathrm{~b}$ & $8.00 \mathrm{a}$ \\
Carbaryl 85\% & $(2.0 \mathrm{~g} / \mathrm{l})$ & 3.25 & 4.00 & $8.75 \mathrm{bcd}$ & $11.00 \mathrm{c}$ & $9.50 \mathrm{a}$ \\
Carbaryl 85\% & $(3.0 \mathrm{~g} / \mathrm{l})$ & 4.25 & 7.00 & $6.00 \mathrm{a}$ & $7.75 \mathrm{a}$ & $7.75 \mathrm{a}$ \\
Control & & 3.50 & 4.75 & $10.75 \mathrm{~d}$ & $12.25 \mathrm{~d}$ & $13.0 \mathrm{~b}$ \\
\hline
\end{tabular}

Note: The same letter in one column shows not significantly different from the LSD test with a confidence level of $5 \%$. DBA= Days before application and DAA= Days after application 
Table 3. The Diadegma sp. population (direct application)

\begin{tabular}{llcccc}
\hline \multirow{2}{*}{ Treatment } & \multirow{2}{*}{$\begin{array}{c}\text { Initial population } \\
\text { (Individuals) }\end{array}$} & \multicolumn{3}{c}{$\begin{array}{c}\text { Population after treatment } \\
\text { (Individuals) }\end{array}$} \\
\cline { 4 - 6 } & & & 24 HAT & 48 HAT & 72 HAT \\
\hline Carbaryl 85\% & $(0.5 \mathrm{~g} / \mathrm{l})$ & 10 & 10.00 & 9.25 & 8.5 \\
Carbaryl 85\% & $(1.0 \mathrm{~g} / \mathrm{l})$ & 10 & 9.75 & 9.25 & 8.5 \\
Carbaryl 85\% & $(1.5 \mathrm{~g} / \mathrm{l})$ & 10 & 10.00 & 9.00 & 8.0 \\
Carbaryl 85\% & $(2.0 \mathrm{~g} / \mathrm{l})$ & 10 & 9.25 & 8.00 & 7.5 \\
Carbaryl 85\% & $(3.0 \mathrm{~g} / \mathrm{l})$ & 10 & 9.25 & 7.75 & 7.0 \\
Control & & 10 & 10.0 & 10.00 & 10.0 \\
\hline
\end{tabular}

The low toxicity of insecticides against Diadegma $\mathrm{sp}$. is probably due to the low penetration rate of compounds through the cuticle of Diadegma sp. (Heong et al., 2013). Insecticide toxicity affects the mortality of the tested insects and affects the behavior and physiology of the tested insects. According to Lemes et al. (2010), the impact of exposure to an insecticide can cause effects on parasitoids, namely lethal effects with indicators of death (mortality) and sub-lethal effects (behavior and biology). Sub-lethal effects or changes in the parasitoids' behavior were seen in the parasitoids that survived after insecticide application, in which uncontrolled parasitoid movements and not recognizing the host can occur. Exposure to insecticides can interfere with parasitoid mobility resulting in uncoordinated movement and can cause the para- sitoids to remain silent or even reject their host (Abbes et al., 2015).

The results for the insecticide carbaryl $85 \%$ with residual exposure (indirectly) did not significantly affect the mortality of Diadegma sp. The results showed that the Diadegma sp. application's effect showed a decrease in the population in the Carbaryl $2.0 \mathrm{~g} / \mathrm{l}$ and $3.0 \mathrm{~g} / \mathrm{l}$ treatments (Table 4). Diadema sp. mortality occurred in the observation 48 and 72 hours after treatment. The highest mortality of Diadegma sp. was in the $3.0 \mathrm{~g} / \mathrm{I}$ with a mortality rate of $17.5 \%$. The low decrease in the average population of Diadegma sp. in testing for the insecticide carbaryl $85 \%$ was indirectly caused by the low effect of insecticide residues with the active ingredient in the carbamate group. Carbamate is an active insecticide ingredient with the lowest residual effect

Table 4. The Diadegma sp. population (Residual application)

\begin{tabular}{|c|c|c|c|c|c|}
\hline \multirow{2}{*}{\multicolumn{2}{|c|}{ Treatment }} & \multirow{3}{*}{$\begin{array}{c}\text { Initial population } \\
\text { (Individuals) }\end{array}$} & \multicolumn{3}{|c|}{$\begin{array}{c}\text { Population after treatment } \\
\text { (Individuals) }\end{array}$} \\
\hline & & & \multirow{2}{*}{$\begin{array}{c}24 \text { HAT } \\
10\end{array}$} & \multirow{2}{*}{$\begin{array}{c}48 \text { HAT } \\
10\end{array}$} & \multirow{2}{*}{$\begin{array}{c}\text { 72 HAT } \\
10.00\end{array}$} \\
\hline Carbaryl 85\% & $(0.5 \mathrm{~g} / \mathrm{l})$ & & & & \\
\hline Carbaryl 85\% & $(1.0 \mathrm{~g} / \mathrm{l})$ & 10 & 10 & 10 & 10.00 \\
\hline Carbaryl 85\% & $(1.5 \mathrm{~g} / \mathrm{l})$ & 10 & 10 & 10 & 10.00 \\
\hline Carbaryl $85 \%$ & $(2.0 \mathrm{~g} / \mathrm{l})$ & 10 & 10 & 10 & 9.75 \\
\hline Carbaryl 85\% & $(3.0 \mathrm{~g} / \mathrm{l})$ & 10 & 10 & 10 & 9.00 \\
\hline Control & $(0.5 \mathrm{~g} / \mathrm{l})$ & 10 & 10 & 10 & 10.00 \\
\hline
\end{tabular}

Note: HAT: Hour after treatment 
than the active ingredients in the pyrethroid and organophosphate groups. The residue of an active insecticide is also influenced by its selectivity (Lemes et al., 2010). Moreover, the residual impact of an insecticide causes mortality in the parasitoids and affects the parasitoids' behavior. According to research by Meilin et al. (2012), the application of Deltamethrin causes adverse effects on the parasitoids Anagrus nilaparvatae such as a decrease in life span, decrease actual and potential meridians, and increase the length of development of offspring.

\section{CONCLUSION}

The insecticides Carbaryl $85 \%$ was not effective in controlling $P$. xylostella, but the population was decreasing. The $85 \%$ carbaryl insecticide with the highest effect in reducing $P$. xylostella populations was $3.0 \mathrm{~g} / \mathrm{l}$. Treatment of the insecticide carbaryl $85 \%$ did not affect the mortality of natural enemies (Diadegma sp.) after direct and indirect testing.

\section{REFERENCES}

Abbes, K., Biondi, A., Kurtulus, A., Ricupero, M., Russo, A., et al. 2015. Combined Non-Target Effects of Insecticide and High Temperature on the Parasitoid Bracon nigricans. PLoS One 10(9): e0138411-e0138411. DOI: 10.1371/journal.pone.0138411.

Capinera, J. 2018. Diamondback moth - Plutella xylostella (Linnaeus). IFAS Extention: 1-4. http://entnemdept.ufl.edu/creatures/veg/leaf/ diamondback_moth.htm.

Heong, K.L., Tan, K.H., Garcia, C.P.F., Liu, Z., and Lu, Z.. 2013. Research Methods in Toxicology and insecticide Resistance Monitoring of Rice Planthoppers (2nd Edition).
Kotta, N.R.E., Trisyono, Y.A., and Wijonarko, A.. 2018. Resistance Level of Plutella xylostella L. (Lepidoptera: Plutellidae) on Cypermethrin in the Regency of Kupang. J. Perlindungan Tanam. Indones. 22(2): 186. DOI: 10.22146/ jpti.24750.

Lemes, F., Bacci, L., Maria, and Fernandes, S. 2010. Impact and Selectivity of Insecticides to Predators and Parasitoids. EntomoBrasilis 3. DOI: 10.12741/ebrasilis.v3i1.52.

Mavrikou, S., Flampouri, K., Moschopoulou, G., Mangana, O., Michaelides, A., et al. 2008. Assessment of organophosphate and carbamate pesticide residues in cigarette tobacco with a novel cell biosensor. Sensors 8(4): 2818-2832. DOI: 10.3390/s8042818.

Meilin, A., Trisyono, Y., Martono, E., and Buchori, D. 2012. The Effects of Deltamethrin Applied At Sublethal Concentrations on The Adults of Anagrus nilaparvatae (Hymenoptera: Mymaridae). ARPN J. Agric. Biol. Sci. 7: 1032-1037.

Morais, S., Dias, E., and Pereira, M. 2012. Carbamates: Human Exposure and Health Effects. p. $21-38$

Mpumi, N., Machunda, R.S., and Mtei, K.M. 2020. Selected Insect Pests of Economic Importance to Brassica oleracea, Their Control Strategies, and the Potential Threat to Environmental Pollution in Africa. Sustain. 12: 3820.

Navik, O., Ramya, R.S., Varshney, R., Jalali, S.K., Shivalingaswamy, T.M., et al. 2019. Integrating biocontrol agents with farmer's practice: impact on diamondback moth, Plutella $x y$ lostella (Linnaeus) (Lepidoptera: Plutellidae), and cabbage yield. Egypt. J. Biol. Pest Control 29(1): 35. DOI: 10.1186/s41938-0190140-x. 
Palmquist, K., Salatas, J., and Fairbrother, A. 2012. Pyrethroid Insecticides: Use, Environmental Fate, and Ecotoxicology. Advances in Integrated Pest Management.

Pinheiro, P.F., de Queiroz, V.T., Rondelli, V.M., Costa , A.V., Marcelino, T. de P., et al. 2013.
Atividade inseticida do óleo essencial de capim-citronela sobre Frankliniella schultzei e Myzus persicae. Cienc. e Agrotecnologia 37 (2): 138-144. doi: 10.1590/S141370542013000200004 . 